DOI 10.31558/2519-2949.2018.4.18

УДК 327(73:55+569.3)"1991"

Павлюк О. І., Вищий державний навчальний заклад Украйни «Буковинський держскний медичний університет»

\title{
ІНІЦІАТИВИ ДЖ. БУША-СТ ЩОДО ВРЕГУЛЮВАННЯ ДВОСТОРОННІХ ВІДНОСИН США $З$ ІРАНОМ ТА КРИЗА ЗАРУЧНИКІВ У ЛІВАНІ 1991 p.
}

Основною метою роботи є дослідження дипломатичних інічіатив адміністрачї Дж. Буша-ст. щоодо врегулювання кризи взаємин США з Іраном у контексті перемовин щэодо звільнення американських заручників у Лівані. Автор простежує еволючію політичних кроків Дж. Буша-ст. щодо поліпшення відносин з Ісламською Республікою Іран та поступову еволюиію американської зовнішньої політики до пасивного стримування Тегерану. У статті проведено аналіз політики іранського президента Х. Рафсанджані щьодо виведення Ірану з міжнародної ізоляції, що розглядається як фактор впливу на двосторонні відносини Вашингтону та Тегерану.

Дж. Буш став третім президентом США, чиї відносини з Тегераном характеризувались напруженістю через захоплення заручників. Хезболла почала захоплення американців в 1982 p., $i$ багато заручників страждали в неволі з того часу, зокрема підполковник В. Хігzінс, який був захоплений у 1981 р. під час служби в Лівані у Організації Об'єднаних Наиій і був убитий в 1989 p. Цей етап в історії двосторонніх відносин став значною перепоною до налагодження зав'язків Вашингтону з Тегераном.

У серпні 1990 р. баланс сил у Перській затоиі різко змінився, коли Ірак вторгся в Кувейт і Сполучені Штати почали передислоковувати війська і військову техніку на Середній Схід, щэо почало дуже турбувати Іран. Автор аналізує зміни у поведінці Ірану та розкриває його вплив на діяльність терористичної організачї Хезболла.

Двостороння співпраия Вашингтону з Тегераном за період президенства Дж. Буша та $X$. Рафсанджані демонструє обережні зустрічні кроки обох сторін, щуо чітко підкреслює недовіру між двома краӥнами та їх керівництва. Це також показує той факт, що кожна краӥна мала справу зі внутрішньополітичною боротьбою і зовнішніми обмеженнями, намагаючись впоратися з викликами.

Відкинувши ідею налагодження контакту з керівництвом Тегерану, адміністрація втратила можливість покращити американо-іранські відносини надалі. Інші виклики перед США у міжнародних відносинах - падіння комунізму, криза в Китаї і війни в Перській заточі - сприяли переходу США у відносинах з Іраном на пасивне стримування Ісламської республіки. Вашингтон в кінцевому підсумку практично ігнорував Тегеран.

Ключові слова: зовнішня політика США, політика Дю. Буша-ст., Іран, Хезболла, Ліван, Перська затока, Х. Рафсанджані.

Із закінченням холодної війни, політична команда Дж. Буша-ст. зіткнулася з радикальними глобальними змінами у світі. Розпад Радянського Союзу ознаменував перемогу США у радянськоамериканській холодній війні та задекларував статус як єдиної наддержави. Але новий статус Сполучених Штатів як домінуючої світової держави не зменшив десятирічну напруженість у відносинах між Вашингтоном і Тегераном. Не покращились відносини і з ліванською шиїтською організацією Хезболла, яка отримувала сприяння та фінансову допомогу з Ірану та у 1982 р. захопила американських заручників, які досі перебували у неволі.

Аналіз останніх досліджень і публікацій. Проблеми американо-іранських відносин в умовах біполярної системи міжнародних відносин розглядають Б. Куіхольм, Г. Сик, Е. Абрахамія, Дж. Марі, Ш. Наджпур. Аналіз зовнішньої політики США щодо Ірану крізь призму регіону Перської затоки здійснюють у своїх працях П. Бредлі, Д. Лонг, Е. Накхіє, Г. Гос, Дж. Фуллер. Особливості міжнародних відносин в умовах холодної війни та у постбіполярному світі у регіоні Близького та Середнього Сходу та вплив на них політики США розглядали такі науковці: Б. Рубін, Дж. Мігліетта, В. Квандт, Л. Хадар.

(C) Павлюк O. I., 2018 
Для розкриття впливу внутрішніх факторів на зовнішню політику Ірану та відносини з США важливими стали роботи Е. Абрахаміана, Г. Кертіса, Е. Хугланда, А. Кордесмена, Р. Рамазані, Е. Хугланд. Варто виокремити науковий доробок англійської дослідниці Д. Мюррей, яка здійснила грунтовне дослідження двосторонніх відносин США з Іраном після Ісламської революції 1979 р. до сучасного часу. Досліджуючи детально механізм прийняття рішень у американській зовнішній політиці, науковець дає нову оцінку американо-іранським відносинам та позиціонує Іран як дуже суперечливу державу, яка водночас була союзником США та «державою-ізгоєм», яка підпадала під жорсткі санкції з боку США і відігравала велику роль у американській війні з тероризмом після подій 11 вересня 2001 p. та, водночас, сприяла терористичним організаціям та робила спроби виготовити ядерну зброю.

Мета роботи полягає у аналізі дипломатичних ініціатив Дж. Буша-ст. щодо відновлення двосторонніх відносини з Іраном у контексті перемовин щодо звільнення американських заручників у Лівані. Досягнення мети обумовило необхідність розв'язання наступних дослідницьких завдань: проаналізувати політичні кроки Дж. Буша-ст. щодо поліпшення відносин з Ісламською Республікою Іран; висвітлити політику виведення Ірану з міжнародної ізоляції Х. Рафсанджані; дослідити вплив Ірану на діяльність терористичної організації Хезболла; охарактеризувати вплив на двосторонні відносини Вашингтону та Тегерану війни у Перській затоці у 1991 р.

У 1989 р. в Ірані відбулись президентські вибори, на яких переміг Х. Рафсанджані спікер парламенту та фактичний командувач збройних сил IPI під час Ірано-іракської війни. Х. Рафсанджані приступив на пост у липні 1989 р., у переломний період для Ірану, оскільки у червні помер духовний лідер аятола Хомейні. Після смерті Хомейні відбулась конституційна реформа, яка скасувала посаду прем'єр-міністра і сформувала президентську систему керівництва та наділяла його значними повноваженнями. У період після смерті аятоли Хомейні, Х. Рафсанджані був домінуючою фігурою у тандемі президента i верховного лідера, які керували Ісламською Республікою. Тому за його керівництва зовнішня, економічна і соціальна політики набули більш прагматичного характеру.

Х. Рафсанджані спробував вивести країну з міжнародної ізоляції та почав відновлювати контакти з сусідніми країнами, зокрема були відновлені дипломатичні відносини з Саудівською Аравією, Марокко, Сгиптом. Він почав економічну лібералізацію, змінюючи планову економіку та дозволяючи вливання вітчизняних та іноземних інвестиції з приватного сектору $[14$, с. 15].

Оскільки Іран здійснював більш прагматичну зовнішню політику під час президентства Х. Рафсанджані, Сполучені Штати взяли курс на глобальне лідерство завдяки поразці Радянського Союзу в Афганістані та подальшому розпаду всієї соціалістичної системи. Єдиний великий конкурент Сполучених Штатів зник у 1991 p., і США почали налагоджувати відносини з новоствореними країнами Східної Свропи та Центральної Азії. Прагматичний i менш антагоністичний, новий уряд в Ірані теж ставав бенефіціаром від поразки військ Радянського Союзу в Афганістані. Крім того, великі надії на зміни у відносинах між Іраном та Сполученими Штатами 3'явились після того як помер Аятола Хомейні. Новим Верховним лідером став Аятола Хаменеї, вирішальну роль у виборі якого відіграв Х. Рафсанджані [1, с. 178].

У 1989 р. відбулися вибори і у США, де перемогу отримав кандидат від республканської партії Дж. Буш (1989-1993рр.). Хоча віце-президент у адміністрації Р. Рейгана і переміг на виборах, він вважався прихильником менш жорсткої лінії, ніж його попередник. Нові президенти двох країн почали своє керівництво у важких умовах. Іран намагався подолати економічні негаразди спричинені затяжною війною з Іраком, проте швидко відновив вплив і престиж у регіоні. Також IPI розпочала активну діяльність з підтримки різних ісламістських організацій. Крім того великого впливу в Лівані набула Хезболла, особливо після ослабленням Організації звільнення Палестини і шиїтського повстання в Іраку. Після захоплення заручників Хезболлою у 1980-х рр., Сполучені Штати та деякі європейські країни заявили, що $є$ підтвердженням підтримки Хезболли Іраном, а також про можливу безпосередню учать IPI та замовлення терактів [4, с. 119].

Ще один фактор, який вплинув на двосторонні відносини, став недавній скандал Іран-контрас, який відбувся під час того, як Республіканська партія була при владі. Таким чином, новий президент від цієї ж партії був дещо скований у закликах до безпосередніх перемовин з Іраном. Тим не менш, Сполучені Штати дійшли висновку, що найшвидший спосіб звільнити заручників - це вплинути на Тегеран. Це і підштовхнуло США на наступний крок.

Успадкувавши недовіру та протистояння у відносинах 3 Ісламською республікою від попередньої адміністрації, Дж. Буш-ст. вирішив сприяти поліпшенню відносин 3 Іраном. Вперше 
після революції Іран пішов на зближення, що характеризували заяви високопосадовців. Зокрема, тогочасний спікер Меджлісу Х. Рафсанджані заявив у січні 1989 р., що замість того, щоб зображати себе «неосвіченими авантюристами, іранці повинні експортувати революцію, взявши участь у кожному міжнародному заході, від Організації Об'єднаних Націй до Олімпійських ігор» [11, c. 204]. Такі декларації означали зміну агресивної зовнішньої політики Ірану на більш помірковану, стримування експорту ісламської революції у сусідні країни та спроби легітимізувати іiі на міжнародному рівні.

Заступник міністра закордонних справ М. Бешараті згодом заявив, що «як пише Коран, хто давнє пом'яне, той лиха не мине, а ми повинні думати про майбутнє» і цим засвідчив крок назустріч до зближення з США [7, с. 29]. I хоча заручники і далі утримувались Хезболою в Лівані, що незмінно поглиблювало конфлікт між США та IPI, Дж. Буш вирішив піти на зустріч і у своїй інавгураційній промові 1989 р. висловив стурбованість у зв'язку з зниклими безвісти американцями i тими, хто в той час перебував у заручниках у Лівані. Він також заявив, що «допомога вітається і буде довго цінуватись» і дав обіцянку: «Доброзичливість породжує доброзичливість» [2].

Дж. Буш став третім президентом США, чиї відносини з Тегераном характеризувались напруженістю через захоплення заручників. Хезболла почала захоплення американців в 1982 р., i багато заручників страждали в неволі з того часу, зокрема підполковник В. Хіггінс, який був захоплений у 1981 р. під час служби в Лівані у Організації Об'єднаних Націй і був убитий в 1989 р. [3]. Цей етап в історії двосторонніх відносин став значною перепоною до налагодження зав'язків Вашингтону з Тегераном.

Проте США намагається залучити Іран до вирішення проблеми з заручниками через співпрацю у ООН і звернувся до Генерального секретаря Хав'єра Переса де Куельяра. Парламентер ООН Дж. Ріссо відвідав Іран та передав президенту послання Дж. Буша, на що іранське керівництво відповіло, що зробить все, що у їх силах, щоб звільнити заручників [15, c. 45]. I вже у серпні 1989 р. у іранській пресі з'являється повідомлення, що IPI допоможе адміністрації Дж. Буша звільнити американських заручників, якщо США поверне іранські активи, які були заморожені з 1979 р. адміністрацією Дж. Картера [5]. У Гаазькому суді розглядався позов Ірану на повернення 12 млрд. дол. проте за даними Державного департаменту, Сполучені Штати заморозили 9.97 млрд. дол. іранських активів після того, як було захоплено американських дипломатів у посольстві США у Тегерані. Після того, як заручники були звільнені в 1981 р. 3.89 млрд. були повернуті в Іран за рішенням суду, а решта залишилась на рахунках ескроу, або були виплачені на вимогу американським компаніям [8, с. 68].

Хоча Білий Дім відразу відкинув пропозицію Тегерану, повторивши свою позицію, що не збирається виплачувати Ірану кошти і військову техніку, яку уряд IPI оцінює у десятки мільярдів. Проте представники адміністрації згодом припустили, що заморожені активи можуть бути звільнені після того, як випустять американських заручників у Лівані [5].

Після того, як Дж. Буш починає процес у Гаазькому трибуналі, щоб показати послідовність своїх намірів співпрацювати з Іраном, президент Х. Рафсанджані робить відкритий крок назустріч та, беручи на себе величезний ризик, посилає лідера Революційної гвардії в Ліван, щоб посприяти звільненню суб'єктів терористичної діяльності [9]. В квітні 1990 р. був звільнений Р. Полхіл перший заручник з часів скандалу «Іран-Контрас» під час адміністрації Р. Рейгана. Проте процес звільнення тривав довго аж до січня 1991 р., коли були звільнені всі американські заручники, а також були повернуті тіла В. Хіггінса та В. Баклі [10].

Хоча знадобилося три роки, щоб IPI домоглася звільнення заручників, керівництво Ісламської республіки було переконане, що вони виконали свою частину угоди і чекали відповідних дій та певних поступок від Сполучених Штатів. Крім того, Іран зв'язався з секретарем Організації Об'єднаних Націй, щоб нагадати США про обіцянку [1, с. 180]. На думку директора 3 питань Середнього Сходу у Раді національної безпеки за адміністрації Дж. Буша та директора аналітичного центру «Рада зовнішніх відносин» Р. Хааса, розкол всередині іранського керівництва, який став більш вираженим після смерті аятолли Хомейні у червні 1989 р., можливо, уповільнив можливості Ірану впливати на звільнення заручників та припинення терористичної діяльності, але те, що було поза політикою не мало значення для чиновників у адміністрації Дж. Буша [14, с. 137].

Державний департамент схилявся в сторону виконання домовленостей та був готовий зняти деякі санкції проти Ірану. Тим не менш, радники Дж. Буша були проти виконання угоди на тій підставі, що Іран збільшив свою підтримку радикальних груп бойовиків на Середньому Сході. Здавалося, що уряд Ірану намагається вести подвійну гру у відносинах з Сполученими Штатами. 
3 одного боку, він тисне на Хезболлу та інші радикальні організації, звільнити заручників, а 3 іншого, сприяє їх терористичній діяльності та надає фінансову допомогу. На думку науковців Університету Південного Miccicini Дж. Марі та Ш. Нагшпур, якщо б Сполучені Штати зняли санкції у відповідь на звільнення заручників, то Іран вийшов би явним переможцем цього гамбіту. Це б збільшило вплив Ірану серед ісламістських організацій, та підвищило його фінансування та сприяння терористичної діяльності [6, с. 150].

У серпні 1990 р. баланс сил у Перській затоці різко змінився, коли Ірак вторгся в Кувейт і Сполучені Штати почали передислоковувати війська і військову техніку на Середній Схід, що почало дуже турбувати Іран. Накопичення сотні тисяч військовослужбовців коаліції Західних держав у Перській затоці, укладання військових угод США з Бахрейном і Об'єднаними Арабськими Еміратами і встановлення військових баз у Саудівській Аравії були додатковим джерелом занепокоєння та ще однією причиною, чому Іран таки погодився посприяти у звільненні заручників у Лівані.

Активна міжнародна діяльність США на пострадянському просторі та укладання угод 3 нещодавно утвореними країн на півночі Ірану, такими як Азербайджан, Туркменістан і Узбекистан тільки посили стурбованість IPI. Науковці Дж. Марі та Ш. Нагшпур припускають, що для того, щоб Іран домігся звільнення заручників, він, цілком можливо мав би піти на поступки радикальним організаціям, наприклад пообіцяти збільшення фінансування. Зрештою, як вони зазначають, Іран не керував жодним з радикальних угрупувань, i його вплив обмежувався навіть на Хезболлу, організацію яка була створена за сприяння та фінансування IPI [6, с. 151].

У той час як члени уряду Сполучених Штатів сперечались над тим, як реагувати на жест «доброї волі» з боку Ірану, бомба вибухнула у ізраїльському посольстві в Буенос-Айресі в Аргентині. Відповідальність за це взяла Організація Ісламського джихаду, яка співпрацювала тоді з Хезболлою та Іраном [4, с. 83]. Ця подія схилила вагання американського істеблішменту у сторону запровадження більш жорсткої лінії поведінки щодо Ірану, а також підтвердила здогадки, що IPI надає підтримку екстремістським рухам. Адміністрація Дж. Буша вирішила, що США не повинні йти на поступки та не будуть виконувати угоду, поки Іран збільшуватиме свою підтримку ісламістських організацій, які протистоять США та Ізраїлю та підривають їх інтереси в регіоні. Відмова Сполучених Штатів, виконувати свою частину договору поставили президента $\mathrm{X}$. Рафсанджані у скрутне становище та послабили його позиції як лідера поміркованої фракції у боротьбі за владу з консервативними радикалами [1, с. 182].

Іранське керівництво було розгніване та розчароване, що їхні зусилля, спрямовані на звільнення заручників не зустрілися з американською «доброзичливістю», а саме з ослабленням санкцій чи визнанням Іраку винуватцем початку ірано-іракської війни 1980-88 рр. Б. Рідел, науковий співробітник Інституту Брукінгса, який працював в той час у ЦРУ, вважає, що саме різноманітні акти тероризму, уяких іранці активно брали участь, значно погіршило відносини та зробило неможливим будь-яке зближення двох країн [12].

Також США відкрито звинуватили Іран у вбивстві десятків іранських емігрантів на Заході і бомбуванні ізраїльського посольства в Буенос-Айресі, вкінці відносини погіршує релігійний указ «фатва» Духовного лідера Ірану, у якій він звертається до мусульман в будь-якій точці світу знайти та стратити британського письменника С. Рушді за його роман «Сатанинські вірші», визнавши книгу блюзнірською і віровідступницькою. Цей указ та вбивство в серпні 1991 р. в Парижі колишнього прем'єр-міністра Ірану Ш. Бахтіяра іранськими агентами значно поглибили згодом суперечності між США та IPI [13].

Президент Х. Рафсанджані зрозумів, що американське керівництво не буде виконувати свою обіцянку і решта п’ять років на посаді президента, більше не ризикував громадською думкою всередині країни, щоб здійснити будь-які подальші спроби налагодити відносини із Заходом. Іран не тільки більше не намагався налагодити відносини, але й відмовився від переговорів чи будь-яких інших контактів із США поки на посаді залишався президент Х. Рафсанджані, що тривало ще і під час першої адміністрації В. Клінтона.

Отже, прагнення адміністрації Дж. Буша-старшого поліпшити відносини з Іраном чітко співпадали із заявами та намірами президента. Проте коли Іран посприяв звільненню останніх американських заручників у Лівані, а Вашингтон зволікав 3 виконанням своєї частини домовленостей, ініціатива президента зійшла нанівець. Двостороння співпраця Вашингтону з Тегераном за період президенства Дж. Буша та Х. Рафсанджані демонструє обережні зустрічні кроки обох сторін, що чітко підкреслює недовіру між двома країнами та їх керівництва. Це також 
показує той факт, що кожна країна мала справу зі внутрішньополітичною боротьбою і зовнішніми обмеженнями, намагаючись впоратися з викликам.

Відкинувши ідею налагодження контакту з керівництвом Тегерану, адміністрація втратила можливість покращити американо-іранські відносини надалі. Інші виклики перед США у міжнародних відносинах - падіння комунізму, криза в Китаї і війни в Перській затоці - сприяли переходу США у відносинах з Іраном на пасивне стримування Ісламської республіки. Вашингтон в кінцевому підсумку практично ігнорував Тегеран.

\section{Бібліографічний список:}

1. Abrahamian E. A History of Modern Iran / Ervand Abrahamian. - Cambridge University Press, 2008 - 228 p.

2. Bush G. Inaugural Address [Електронний ресурс] / George Bush // The American Presidency Project. 1989. - 20 Jan. - Режим доступу: http://www.presidency.ucsb.edu/ws/?pid=16610

3. Col. Higgins Was Hanged, Shiites Say; Bush Outraged : Another Hostage Threatened [Електронний ресурс] // Los Angeles Times. - 1989. - 31 July. - Режим доступу: http://articles.latimes.com/1989-07-31/news/mn-492_1_ hezbollah

4. Cordesman A. Iran's Weapons of Mass Destruction: The Real and Potential Threat / Anthony H. Cordesman , Khalid R. Al-Rodhan. - Washington : Center for Strategic \& International Studies, 2006 - 380 p.

5. Dowd M. Iran is Reported Rready for a Deal to Recover Assets [Електронний ресурс] / Maureen Dowd // The New York Times. - 1989. - 9 Aug. - Режим доступу: http://www.nytimes.com/1989/08/09/world/iran-isreported-ready-for-a-deal-to-recover-assets.html

6. Marie J. Revolutionary Iran and the United States: Low-intensity Conflict in the Islamic World (Persian Gulf) / Joseph J. St. Marie, Shahdad Naghshpour - Ashgate, 2011. - 214 p.

7. Marschall C. Iran's Persian Gulf Policy: From Khomeini to Khatami / Dr Christin Marschall. - [S. 1.] : Routledge, 2003. $-272 \mathrm{p}$.

8. Murray D. US Foreign Policy and Iran: American-Iranian Relations Since the Islamic Revolution.

Contemporary Security Studies / Donette Murray. - Oxon ; New York : Routledge, 2010. - 247 p.

9. Percy N. US - Iran: Dialogua of the Deaf? [Електронний ресурc] / Norma Percy // BBC: Iran and the West. 2009. - 10 Febr. - Режим доступу: http://news.bbc.co.uk/2/hi/7875129.stm

10. Polhill R. Held Hostage for 3 Years in Mideast [Електронний ресурс] / Robert Polhill // Los Angeles

Times. - 1999. - July. - Режим доступу: http://articles.latimes.com/1999/jul/03/news/mn-52601

11. Ramazani R. K. Iran's Foreign Policy: Contending Orientations / R. K. Ramazani // Middle East Journal. 1989. - Vol. 43. - № 2. - P. 202-217.

12. Riedel B. Islamism Is Not Unstoppable [Електронний pecypc] / Bruce O. Riedel // Middle East Quarterly. 1999. - Vol. 6, № 4. - Режим доступу: http://www.meforum.org/452/interview-with-bruce-o-riedel

13. Shams S. The Rushdie fatwa: 25 years on [Електронний ресурс] / Shamil Shams // DW. - 2012. - Febr. Режим доступу: http://www.dw.de/the-rushdie-fatwa-25-years-on/a-17425932

14. The Iran primer: power, politics, and U.S. policy / ed. Robin Wright. - Washington, DC : United States Institute of Peace Press, 2010. - $300 \mathrm{p}$.

15. Wehrey F. Dangerous But Not Omnipotent: Exploring the Reach and Limitations of Iranian Power in the Middle East / Frederic Wehrey, David E. Thaler, Nora Bensahel, [etc.]. - [S. 1.] : RAND Corporation, 2009 - 230 p.

\section{Pavliuk O. I., George W. Bush Initiatives on the Settlement of US-Iran Bilateral Relations and Hostage Crisis in Lebanon in 1991}

The main purpose of the paper is to study the diplomatic initiatives of the administration of George $W$. Bush. on the crisis settlement of the US-Iran relationship in the context of talks on the release of American hostages in Lebanon. The author traces the evolution of the political steps of George W. Bush. on improving relations with the Islamic Republic of Iran and the gradual evolution of US foreign policy towards passive deterrence of Tehran. The article analyzes the policies of Iranian President H. Rafsanjani for Iran's withdrawal from international isolation, which is considered as a factor affecting bilateral relations between Washington and Tehran.

George W. Bush became the third US president whose relations with Tehran were characterized by tensions due to the seizure of hostages. Hezbollah began to capture Americans in 1982, and many hostages had been captive since then, including Lt. Col. W. Higgins, who was captured in 1981 while serving in Lebanon at the United Nations and was killed in 1989. This stage in the history of bilateral relations has become a significant obstacle to the establishment of political ties between Washington and Tehran.

In August 1990, the balance of power in the Persian Gulf changed dramatically when Iraq invaded Kuwait and the United States began re-deploying troops and military equipment to the Middle East, which began to bother Iran. The author analyzes changes in Iran's behavior and reveals its influence on terrorist organization Hezbollah. 
Bilateral cooperation between Washington and Tehran during the period of the presidency of George $W$. Bush and H. Rafsanjani demonstrates cautious counter-steps by both sides, which clearly highlights the distrust between the two countries and their leadership. It also shows the fact that each country was dealing with internal political struggle and external constraints, trying to cope with the challenges.

Rejecting the idea of establishing contact with the leadership of Tehran, the administration has lost the opportunity to improve US-Iranian relations in the future. Other challenges facing the US in international affairs were the fall of communism, the crisis in China and the Gulf War. They have contributed to the US transition in relations with Iran on the passive containment of the Islamic Republic. Washington eventually practically ignored Tehran.

Key words: US foreign policy, policy of George W. Bush, Iran, Hezbollah, Lebanon, Persian Gulf, H. Rafsanjani. 